\title{
FAKTOR INDIVIDU DALAM ORGANISASI
}

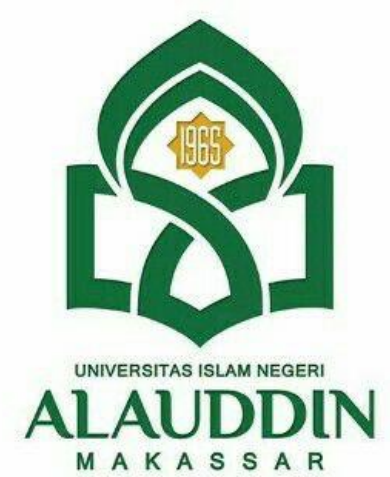

MAKALAH

Diseminarkan Pada Mata Kuliah Pengantar Manajemen Program Studi Perbankan Syariah Semester I Tahun 2021

Oleh :

Muh. Irwan Arfin

NIM. 90500121031

Dosen Pengajar:

Dra. Hj. Nuraeni Gani. MM

PROGRAM STUDI PERBANKAN SYARIAH FAKULTAS EKONOMI DAN BISNIS ISLAM

UIN ALAUDDIN MAKASSAR 2021 
KATA PENGANTAR

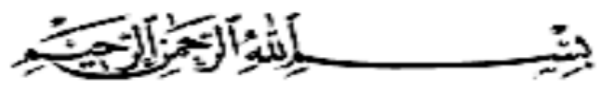

Puji syukur kehadirat Allah SWT yang telah memberikan rahmat dan hidayah-Nya sehingga saya dapat menyelesaikan tugas makalah yang berjudul Faktor Individu Dalam Organisasi ini tepat pada waktunya.

Adapun tujuan dari penulisan dari makalah ini adalah untuk memenuhi tugas Dra. Hj. Nuraeni Gani. MM. pada bidang studi Pengantar Manajemen. Selain itu, makalah ini juga bertujuan untuk menambah wawasan tentang Faktor Individu Dalam Organisasi dan juga bagi penulis.

Saya mengucapkan terima kasih kepada ibu Dra. Hj. Nuraeni Gani. MM. selaku Dosen bidang studi Pengantar Manajemen yang telah memberikan tugas ini sehingga dapat menambah pengetahuan dan wawasan sesuai dengan bidang studi yang saya tekuni.

Saya menyadari, makalah yang saya tulis ini masih jauh dari kata sempurna. Oleh karena itu, kritik dan saran yang membangun akan saya nantikan demi kesempurnaan makalah ini.

Bulukumba, 02 Desember 2021

Muh. Irwan Arfin 


\section{DAFTAR ISI}

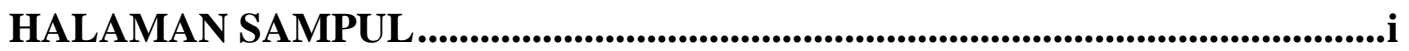

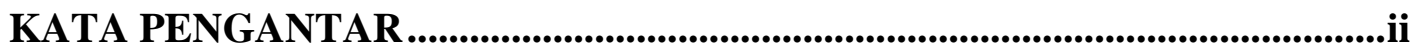

DAFTAR ISI .............................................................................................................ii

BAB I PENDAHULUAN ...............................................................................1
A. Latar Belakang...
1
B. Rumusan Masalah .................................................................................. 3

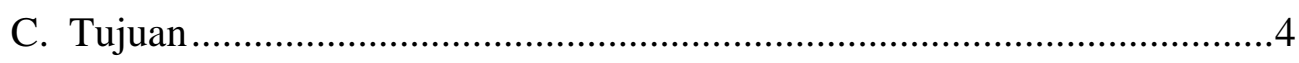

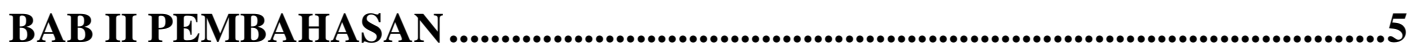

A. Definisi Perilaku Individu Dalam Organisasi........................................5

B. Tingkatan Analisa Perilaku Individu dalam Organisasi ......................... 11

C. Pendekatan-Pendekatan untuk Memahami Perilaku Individu ...................11

D. Konsep Perilaku Individu dalam Organisasi Di Era Globalisasi..............13

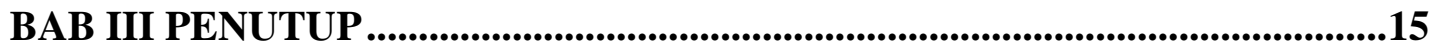

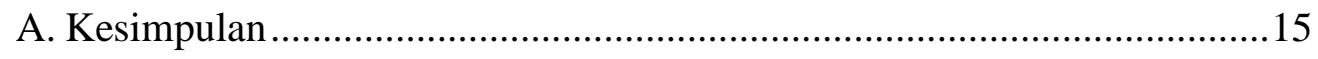

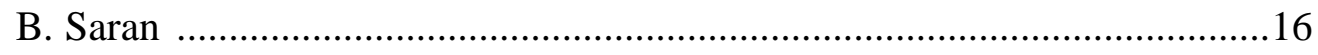

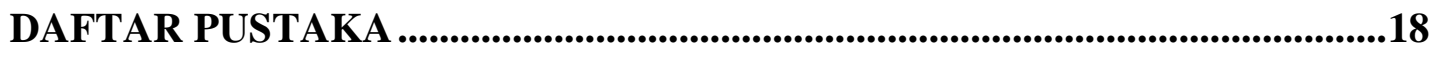




\section{BAB I \\ PENDAHULUAN}

\section{A. Latar Belakang}

Faktor individu sangat berpengaruh dalam organisasi. Kunci utama dalam fungsipengarahan dan implementasi adalah pemahaman atas karakteristik dan peran individu dalamorganisasi. Keragaman karakteristik individu perlu dipahami manajer sebelum implementasidan fungsi pengarahan dilakukan. Hal tersebut disebabkan karena keragaman individu dapatmemberikan dampak berlawanan satu sama lain. Dampak positif ketika keragaman tersebutmenjadi potensi untuk saling melengkapi, atau sebaliknya, dampak negatif sebagai sumberkonflik bagi organisasi.

Pada dasarnya, setiap individu memiliki ciri-ciri yang berbeda. Individu yang saling bergabung akan membentuk kelompok atau masyarakat. Individu tersebut akan memiliki karakteristik yang sama dengan kelompok di mana dirinya bergabung. Individu berasal dari kata latin, "individuum" yang artinya tak terbagi. Kata individu merupakan sebutan yang dapat untuk menyatakan suatu kesatuan yang paling kecil dan terbatas. Kata individu bukan berarti manusia sebagai keseluruhan yang tak dapat dibagi melainkan sebagai kesatuan yang terbatas yaitu sebagai manusia perseorangan, demikian pendapat 
abdilah khusu Individu menurut konsep Sosiologis berarti manusia yang hidup berdiri sendiri. ${ }^{1}$

Menurut Anwar . P (2010) individu yang normal adalah individu yang memiliki integritas yang tinggi antara fungsi psikis (rohani) dan fisiknya (jasmaniah). Dengan adanya integritas yang tinggi antara fungsi psikis dan fisik, maka individu tersebut memiliki konsentrasi diri yang baik. Adapun dimensi dari individu adalah: ${ }^{2}$

1. Individu yang memiliki integritas yang tinggi

2. Fungsi psikis (rohani).

3. Fungsi fisiknya (jasmaniah).

Dalam berorganisasi setiap individu dapat berinteraksi dengan semua struktur yang terkait baik itu secara langsung maupun secara tidak langsung kepada organisasi yang mereka pilih. ${ }^{3}$ Agar dapat berinteraksi secara efektif setiap individu bisa berpartisipasi pada organisasi yang bersangkutan. Dengan berpartisipasi setiap individu dapat lebih mengetahui hal-hal apa saja yang harus dilakukan. ${ }^{4}$

Menurut Robbins(1994) mengatakan, bahwa organisasiadalah kesatuan sosial yang dikoordinasikansecara sadar, dengan sebuah batasan yangrelatif

\footnotetext{
${ }^{1}$ Bagus, Lorens. 1996. Kamus Filsafat. Jakarta: PT.Gramedia Pustaka Utama. Hal 19.

${ }^{2}$ Riyadi, S., \& Widiastuti, T. (2013). Faktor-Faktor yang Mempengaruhi Perilaku Individu dalam Organisasi. Jurnal Ilmiah Aset, 15(1), 33-41.

${ }^{3}$ WS, Winkel. 1997. Psikologi Pendidikan dan Evaluasi Belajar. Jakarta: Gramedia.Hlm.75

${ }^{4}$ Keith Davis, Human Relations at Work, (New York, San Francisco, Toronto, London: 1962).Hlm.15-19
} 
dapat diidentifikasi, yang bekerja atas dasar yang relatif terus menerus untuk mencapai suatu tujuan bersama atau sekelompok tujuan. ${ }^{5}$

Menurut John D.Millet (dalam Sutarto, 2002) Organisasi adalah kerangka struktur dalam mana pekerjaan dari banyak orang dilakukan untuk pencapaian maksud bersama. Sebagai demikian adalah sistem pengenai penugasan pekerjaan diantara kelompok-kelompok orang yang mengkhususkan diri dalam tahap-tahap khusus dari suatu tugas bersama. Organisasi selain dipandang sebagai wadah kegiatan orang juga dipandang sebagai proses, yaitu menyoroti interaksi diantara orang-orang yang menjadi anggota organisasi. Keberhasilan suatu organisasi ditentukan oleh kualitas sumberdaya manusia yang saling berinteraksi dan mengembangkan organisasi yang bersangkutan. Organisasi dalam meningkatkan Sumber Daya Manusia dalam rangka mengoptimalkan kinerja pegawai tidak terlepas dari pemberdayaan potensiyang ada. Adapun dimensi dari organisasi adalah: ${ }^{6}$

1. Kerangka struktur

2. Tujuan bersama

3. Sistem penugasan pekerjaan.

\section{B. Rumusan Masalah}

Berdasarkan latar belakang yang telah penulis uraikan, maka pokok masalah yang diangkat dalam penelitian ini adalah:

1. Apa yang dimaksud dengan perilaku individu?

\footnotetext{
${ }^{5}$ Riyadi, S., \& Widiastuti, T. (2013). Faktor-Faktor yang Mempengaruhi Perilaku Individu dalam Organisasi. Jurnal Ilmiah Aset, 15(1), 33-41.

${ }^{6}$ Riyadi, S., \& Widiastuti, T. (2013). Faktor-Faktor yang Mempengaruhi Perilaku Individu dalam Organisasi. Jurnal Ilmiah Aset, 15(1), 33-41.
} 
2. Apa saja tingkatan analisis dalam perilaku organisasi?

3. Bagaimana pendekatan-pendekatan untuk memahami perilaku individu?

4. Apa saja konsep mengenai perilaku individu dalam organisasi?

5. Bagaimana perilaku individu dalam organisasi?

\section{Tujuan}

Berdasarkan latar belakang seperti diatas maka akan timbul beberapa tujuan penelitian sebagai berikut :

1. Untuk memenuhi tugas mata kuliah Akidah Akhlak.

2. Tidak hanya memenuhi tugas mata kuliah dari dosen pengampu tapi jugadapat mengetahui konsep yang dijelaskan dalam makalah ini.

3. Dan tidak hanya mengetahui akan tetapi juga dapat benar-benar memahamiapa yang telah dijelaskan dalam makalah ini. 


\section{BAB II}

\section{PEMBAHASAN}

\section{A. Definisi Perilaku Individu Dalam Organisasi}

Perilaku individu dalam organisasi adalah bentuk interaksi antara karakteristik individu dengan karakteristik organisasi. Setiap individu dalam organisasi, semuanya akan berperilaku berbeda satu sama lain, dan perilakunya adalah ditentukan oleh masing-masing lingkungannya yang memang berbeda. Individu membawa ke dalam tatanan organisasi kemampuan, kepercayaan pribadi, pengharapan kebutuhan dan pengalaman masa lalunya. Karakteristik yang dipunyai individu ini akan dibawanya manakala memasuki lingkungan baru yaitu oraganisasi atau yg lainnya. Organisasi juga merupakan suatu lingkungan yang mempunyai karakteristik seperti keteraturan yang diwujudkan dalam susunan hirarki, pekerjaan, tugas, wewenang, tanggung jawab, sistem penggajian, sistem pengendalian, dan sebagainya.

Perilaku individu juga dapat dipahami dengan mempelajari karakteristik individu. Nimran dalam Sopiah (2008) menjelaskan karakteristik yang melekat pada individu terdiri dari ciri-ciri biografis, kepribadian, persepsi dan sikap. Berikut adalah penjelasan dari masing-masing karakteristik tersebut.

1. Ciri - ciri biografis, yaitu ciri -ciri yang melekat pada individu. Antara lain:

a. Umur, dijelaskan secara empiris bahwa umur berpengaruh terhadap bagaimana perilaku seorang individu, termasuk bagaimana kemampuannya untuk bekerja, merespon stimulus yang dilancarkan 
oleh individu lainnya. Setidaknya ada tiga alasan yang menjadikan umur penting untuk dikaji.

b. Jenis Kelamin, penelitian membuktikan bahwa sebenarnya kinerja pria dan wanita dalam menangani pekerjaan relatif sama. Keduanya hampir sama konsistensinya dalam memecahkan masalah, keterampilan analitis dorongan kompetitif, motivasi, sosiabilitas, dan kemampuan belajar.

c. Status Perkawinan, pemaknaan tentang pekerjaan akan berbeda antara karyawan yang single dengan karyawan yang sudah menikah. penelitian membuktikan bahwa orang yang telah berumah tangga relatif lebih baik dibandingkan dengan single baik ditinjau dari segi absensi. Keluar beralih kerja dan kepuasan kerja.

d. Jumlah atau Banyaknya Tanggungan, banyak penelitian menunjukkan bahwa semakin banyak jumlah tanggungan dalam keluarga berpengaruh terhadap produktivitas kerja karyawan.

e. Masa Kerja, relevansi masa kerja adalah berkaitan langsung dengan senioritas dalam pekerjaan. Artinya tidak relevan membandingkan pria-wanita-tua-muda dan seterusnya karena penelitian menunjukkan bahwa belum tentu yang lebih lama pada pekerjaan memiliki produktifitas yang lebih tinggi.

2. Kepribadian

Robin dallam sopiah (2008) mengemukakan," personality is the dynamic organization within the individual of those psychophycal systems 
that determine his unique adjustment to this environment. Nimran dalam sopiah (2008) memaknainya,"kepribadian sebagai pengorganisasian yang dinamis dari sistem psikofisik dalam diri individu yang menentukan penyesuaian diri dengan lingkungannya." dia menambahkan bahwa kepribadian sebagai keseluruhan cara bagaimana individu beraksi dan berinteraksi dengan orang lain. Robbins dalam sopiah (2008) mengartikan kepribadian sebagai cara dengan mana seseorang bereaksi dan berinteraksi dengan orang lain. Adapun karakteristik kepribadian yang popular di antaranya adalah agresif ,malu, pasrah, malas, ambisius, setia, jujur. Semakin konsisten karakteristik tersebut di saat merepons lingkungan, hal itu menunjukkan faktor keturunan atas pembawaan (traits) merupakan faktor yang penting dalam membentuk keribadian seseorang.

Kunarto (2001) menyebutkan bahwa temperament we are born with, sedangkan character we have to make. Berangkat dari pendapat ini, pribadi seseorang selalu diwarnai oleh temperamen dan sekaligus karakter. Temperamen berwarna sifat-sifat yang diperoleh dari keturunan. Sedangkan karakter terbentuk oleh lingkungan dan situasi. Interaksi antara temperamen dan karakter itu yang membentuk kepribadian seseorang. Orang yang karakternya terbentuk paada lingkungan dan budaya kerja yang tinggi akan cenderung serius, ambisius, dan agresif. Sedangkan orang yang berada pada lingkungan dan budaya yang menekankan pada pentingnya bergaul baik dengan orang lain, maka ia akan lebih memprioritaskan keluarga dibandingkan kerja dan karier. 


\section{Sikap (Attitude)}

Sikap merupakan satu faktor yang harus dipahami kita dapat memahami perilaku orang lain. Dengan saling memahami individu maka organisasi akan dapat dikelola dengan baik. Definisi sikap dapat dijelaskan dalam tiga komponen sikap, yaitu afektif, kognitif dan psikomotorik. Afektif berkenaan dengan komponen emosional atau perasaan sesorang. Komponon kognitif ini berkaitan dengan proses berfikir yang menekankan pada rasionalitas dan logika. Komponen psikomotorik merupakan kecenderungan seseorang dalam bertindak terhadap lingkungannya.

4. Kemampuan

Yang dimaksud dengan istilah kemampuan adalah kapasitas seseorang untuk melaksanakan beberapa kegiatan dalam satu pekerjaab. Pencapaian tujuanorganisasi atau manajemen yang berhasil adalah kemampuan seorang pemimpin untuk mengeksploitasikan kelebihan sebesar-besarnya dan menekankan kekurangannya dari berbagai orang untuk bersama-sama meningkatkan produktifitas. Kategori dikelompokkan menjadi dua yaitu kemampuan intelektual dan kemampuan phisik.

- Kemampuan intelektual adalah kemampuan yang diperlukan untuk menjalankan kegiatan mental. Untuk mengungkap kemampuan ini digunakan tes IQ yang berusaha mengeksplorasi dimensi kecerdasan numeris yaitu kemampuan berhitung dengan cepat dan tepat, pemahaman verbal yaitu kemampuan memahami apa yang dibaca dan 
didengar serta relasinya satu sama lain, kecepatan perseptual yaitu kemampuan mengenali kemiripan dan beda visual dengan cepat dan tepat, penalaran induktif yaitu kemampuan mengenali suatu urutan secara logis dalam suatu masalah dan kemdian memecahkan masalah tersebut, penalaran deduktif yaitu kemampuan menggunakan logika dan menilai implikasi dari suatu argumen, visualisasi ruang yaitu kemampuan membayangkan bagaimana suatu objek akan tampak seandainya posisinya dalam ruang dirubah, ingatan (memory) yaitu kemampuan menahan dan mengenang kembali pengalaman masa lalu. Untuk pekerjaan yang memerlukan rutinitas tinggi dan tidak memerlukan intelektualitas tinggi, IQ tinggi tidak ada relevansinya dengan kinerja. Namun pemahaman verbal, kecepatan persepsi, visualisasi ruand dan ingatan banyak diperlukan di berbagai bidang pekerjaan. Sehingga tes IQ tetap diperlukan.

- Kemampuan fisik adalah kemampuan yang diperlukan untuk melakukan tugas-tugas yang menuntut stamina, kecekatan, kekuatan dan keterampilan.

Karyawan yang mempunyai kemampuan intelektual dan fisiknya tidak sesuai dengan tuntutan pekerjaan, sipastikan akan merupakan penghambat pencapaian tujuan kinerja atau produktifitas.

5. Persepsi

Gitosudarmo, I (1997) memberikan definisi persepsi sebagai suatu proses memperhatikan dan menyeleksi, mengorganisasikan, dan menafsirkan 
stimulus lingkungan. Dia menambahkan bahwa ada sejumlah faktor yang mempengaruhi persepsi, diantaranya :

- Ukuran

- Intensitas. Semakin tinggi tingkat intensitas stimulus maka akan semakin besar kemungkinannya untuk dipersepsikan.

- Frekuensi. Semakin sering frekuensi suatu stimulus maka akan semakin dipersepsikan orang. Misalnya perusahaan yang gencar mengiklankan produknya di berbagai media.

- Kontras. Stimulus yang kontras / menncolok dengan lingkungannya akan semakin dipersepsikan orang. Seseorang yang tampil "beda" secara fisik akan semakin dipersepsikan banyak orang.

- Gerakan. Stimulus dengan gerakan yang lebih banyak akan semakin dipersepsikan orang dibandingkan dengan stimulus yang gerakannya kurang. Misalnya di suatu ruangan yang hening, semua diam, tiba-tiba ada seseorang yang bergerak, maka semua orang di ruangan tersebut akan memperhatikan orang yang bergerak itu.

- Perubahan/ stimulis yang berubah-ubah akan menarik untuk diparhatikan dibandingkan dengan stimulus yang tetap. Misalnya lampu yang nyalanya berkelip-kelip atau memiliki warna yang bermacam-macam akan lebih menarik perhatian.

- Baru. Suatu stimulus baru akan lebih menarik perhatian orang dibanding stimulus lama. Misalnya buku terbitan baru tentu akan lebih menarik perhatian publik dibangingkan buku terbitan lama. 
- Unik. Semakin unik suatu objek atau kejadian maka akan semakin menarik orang untuk memperhatikannya.

\section{B. Tingkatan Analisa Perilaku Individu dalam Organisasi}

Kejadian atau permasalahan yang terjadi dalam organisasi dapat dianalisis dari tiga tingkatan yaitu sebagai berikut ${ }^{7}$ :

1. Tingkat individu, kejadian yang terjadi dalam organisasi dianalisis dalam hubungannya denganperilaku seseorang dan interaksi kepribadian dalam suatu situasi. Masing-masing individu dalam suatu organisasi memiliki sikap, kepribadian, nilai, danpengalaman yang berbeda-beda yang mempengaruhinya dalam berperilaku.

2. Tingkat kelompok, perilaku anggota kelompok dipengaruhi oleh dinamika anggota kelompok,aturan kelompok, aturan kelompok dan nilai yang dianut oleh kelompok.

3. Tingkat organisasi, berbagai kejadian yang terjadi dalam kontek struktur organisasi, struktur danposisi seseorang dalam organisasi membawa pengaruh pada setiap interaksisosial dalam organisasi.

\section{Pendekatan-Pendekatan untuk Memahami Perilaku Individu}

Manusia yang bekerjasama dalam organisasi memiliki keunikan masingmasingnya karena mereka datang dengan latar belakang yang berbeda seperti budaya, umur, pendidikan, pengalaman, kebutuhan, motivasi dan lain-lain. Oleh karena itu para manajer dalam memahami, mengarahkan dan mengelola perilaku orang-orang yang ada dalam organisasinya, baik secara individual

\footnotetext{
${ }^{7}$ Tewal, B., Pandowo, M. C. H., \& Tawas, H. N. (2017). Perilaku Organisasi.
} 
maupun kelompok dapat memanfaatkan teori, metode dan prinsip berbagai ilmu perilaku dan ilmu sosial seperti Psikologi, Psikologi Sosial, Sosiologi, Antropologi, Ilmu Politik, Ilmu Ekonomi dan Ilmu Manajemen (Greenberg \& Baron, 2008: 6-7; Robbins \& Judge, 2013: 13-14, Gibson, 2012: 7) ${ }^{8}$

Untuk memahami perilaku individu dapat menggunakan pendekatan yangdikelompokan menjadi tiga yaitu sebagai berikut:

1. Pendekatan kognitif adalah perilaku oleh suatu rangsangan, dimana perilakuindividu terjadi atau timbul dikarenakan adanya rangsangan sehingga timbulahrespon atas rangsangan tersebut. Contohnya jika kita bertemu dengan temandan kemudian dia bersikap baik terhadap kita, tentu saja sebaliknya kitapunakan bersikap baik pula.

2. Pendekatan penguatan adalah perilaku yang dipengaruhi oleh gerakan refleksyang digerakan oleh sistem syaraf motorik yang ada di otak kita. Contohnya jika tangan kita terkena api, maka secara otomatis kita akan menjauhkan atau menarik tangan dari api tersebut.

3. Pendekatan psikoanalitis adalah perilaku yang dipengaruhi oleh kepribadian, sedangkan individu yang memiliki pribadi yang baik adalah individu yang telahmatang yaitu orang yang dapat membedakan mana yang baik dan tidak baik bagi dirinya dan lingkungannya. Orang yang tidak semata-mata mementingkankepentingan pribadi saja, melainkan juga kepentingan lingkungan.

\footnotetext{
${ }^{8}$ Tewal, B., Pandowo, M. C. H., \& Tawas, H. N. (2017). Perilaku Organisasi.
} 


\section{Konsep Perilaku Individu dalam Organisasi Di Era Globalisasi}

Perilaku Organisasi adalah suatu disiplin ilmu yang mempelajari bagaimana seharusnya perilaku tingkat individu, tingkat kelompok, serta dampaknya terhadap kinerja (baik kinerja individual, kelompok, maupun organisasi).

Perilaku organisasi juga dikenal sebagai Studi tentang organisasi. Studi ini adalah sebuah bidang yang mempelajari organisasi, dengan memanfaatkan metode-metode dari ekonomi, sosiologi, ilmu politik, antropologi dan psikologi. Disiplindisiplin lain yang terkait dengan studi ini adalah studi tentang Sumber daya manusia dan psikologi industri serta teori organisasi.

Studi organisasi adalah telaah tentang pribadi dan dinamika kelompok dan konteks organisasi, serta sifat organisasi itu sendiri. Setiap kali orang berinteraksi dalam organisasi, banyak faktor yang ikut bermain. Studi organisasi berusaha untuk memahami dan menyusun model-model dari faktorfaktor ini.

Hal ini sama dengan semua ilmu sosial, perilaku organisasi berusaha untuk mengontrol, memprediksikan, dan menjelaskan. Namun ada sejumlah kontroversi mengenai dampak etis dari pemusatan perhatian terhadap perilaku pekerja. Karena itu, perilaku organisasi (dan studi yang berdekatan dengannya, yaitu psikologi industri) kadang-kadang dituduh telah menjadi alat ilmiah bagi pihak yang berkuasa. Terlepas dari tuduhan-tuduhan itu, Perilaku Organisasi 
dapat memainkan peranan penting dalam perkembangan organisasi dan keberhasilan kerja.

Walaupun studi mengacu kepada Max Weber dan para pakar yang sebelumnya, studi organisasi biasanya dianggap baru dimulai sebagai disiplin akademik bersamaan dengan munculnya manajemen ilmiah pada tahun 1890an, dengan Taylorisme yang mewakili puncak dari gerakan ini. Para tokoh manajemen ilmiah berpendapat bahwa rasionalisasi terhadap organisasi dengan rangkaian instruksi dan studi tentang gerak-waktu akan menyebabkan peningkatan produktivitas. Studi tentang berbagai sistem kompensasi pun dilakukan.

Setelah Perang Dunia I, fokus dari studi organisasi bergeser kepada analisis tentang bagaimana faktor-faktor manusia dan psikologi mempengaruhi organisasi. Ini adalah transformasi yang didorong oleh penemuan tentang Dampak Hawthorne. Gerakan hubungan antar manusia ini lebih terpusat pada tim, motivasi, dan aktualisasi tujuan-tujuan individu di dalam organisasi. 


\section{BAB III}

\section{PENUTUP}

\section{A. Kesimpulan}

Perilaku individu dalam organisasi dipengaruhi oleh persepsi,kepribadian dan emosi individu tersebut, dimana kita dapat menilai ataumenafsirkan perilaku dengan cara mengamati pola kebiasaan dan peraturan-peraturan yang ada. Perilaku setiap individu satu dengan yang lainnyaberbeda sehingga diperlukan suatu pendekatan untuk menyatukan individu-individu tersebut agar dapat mencapai tujuan secara bersama-sama, adapu nselain dari menafsirkan perilaku individu untuk mengetahui tujuan individutersebut bisa menggunakan komunikasi sebagai media untuk mengetahui individu tersebut.

Terdapat beberapa perbedaan karakteristik yang terdapat pada dirisetiap individu. Diantara beberapa karakteristik itu yaitu perbedaan mengenai kecerdasan dan potensi yang dimiliki oleh masing-masing individu. Diatastelah dipaparkan beberapa kecerdasan yang dimiliki oleh setiap individu, halitu merupakan acuan bagi seorang manajer agar dapat memahami apa sajayang perlu dilakukan dalam mengorganisir setiap individu yang ada dalam setiap organisasi dengan mengoptimalkan semua kecerdasan yang ia miliki serta menyesuaikan setiap perilaku yang tercermin sesuai dengan kecerdasan yang masing-masing individu miliki.

Dengan perbedaan kecerdasan yang dimiliki oleh setiap individu, maka perilaku yang akan terwujud pun akan berbeda pada setiap diri individu 
tersebut. Dengan setiap perbedaan kecerdasan yang dimiliki oleh setiap individu akan mempengaruhi kepada setiap perilaku individu. Telah banyak dilakukan mengenai pelatihan-pelatihan mengenai kecerdasan diatas, yang diharapkan agar setiap individu apat meningkatkan setiap kinerjanya. Bila setiap individu mempunyai perpaduan antara semua kecerdasan diatas, makaakan berdampak baik pada individu tersebut begitu pula pada organisasi yangdimasukinya.

Bila setiap individu memiliki semua kecerdasan diatas, organisasi akan berjalan lancar dan tujuan akan tercapai. Setiap individu yang memiliki kecerdasan social, maka kerjasama yang baik akan terjalin antar sesama anggota maupun kelompok. Serta bila individu memiliki kecerdasan ESQ, maka diantara setiap anggota, kelompok, atasan dengan bawahan akant erdapat suatu kepercayaan antar satu sama lain yang kuat, karena setiap individu dalam kelompok mempunyai akhlak yang baik. Oleh sebab itu dalam setiap organisasi dibutuhkan suatu kecerdasan yang seimbang yang dimiliki oleh setiap individu organisasi tersebut.

\section{B. Saran}

Sebagai mahasiswa hendaknya tidak hanya sekedar mengerti akan teoriteori yang dijelaskan sebelumnya, akan lebih baik jika kita dapat menerapkannya dalam kehidupan sehari-hari dimulai dari hal terkecil dalamsebuah organisasi yang dapat menjadi sebuah bekal untuk masa depan mengahadapi situasi sesungguhnya. Maka sebagai Agent Of Change kita harus 
memaknai setiap kalimat yang tertulis didalam makalah yang telah dijelaskan sebelumnya untuk mendapatkan manfaat dari kegiatan membaca makalah ini dan dapat menerapkannya di kehidupan yang sesungguhnya. Dan tidak hanya menguasai materi akan tetapi sulit untuk membawanya didunia kerja kelak saat menghadapi masa kerja setelah lulus dari perguruan tinggi. 


\section{DAFTAR PUSTAKA}

Tewal, Berhard, Merinda Ch H. Pandowo, and Hendra N. Tawas. "Perilaku Organisasi." (2017).

Riyadi, Sigit, and Tantri Widiastuti. "Faktor-Faktor yang Mempengaruhi Perilaku Individu dalam Organisasi." Jurnal Ilmiah Aset 15.1 (2013): 33-41.

MM, Tine Yuliantini. "Perilaku organisasi." (2010).

https://id.wikipedia.org/wiki/Organisasi\#cite_note-7

http://kartika-s-n-fisip08.web.unair.ac.id/artikel_detail-37086-hardskill\%20-

PERILAKU\%20INDIVIDU\%20DALAM\%20ORGANISASI\%20.html

https://www.coursehero.com/file/p60eg2t/B-TINGKATAN-ANALISA-DALAMPERILAKU-ORGANISASI-Kejadian-atau-permasalahan-yang/

https://www.academia.edu/22208951/MAKALAH_Perilaku_Individu_dalam_Org anisasi 